\title{
Mathematical Reasoning Ability of Grade IV Elementary School Students on Polygon Materials
}

\section{Gofur Ahmad1 ${ }^{*}$, Sary Ryky Mandar ${ }^{2}$, Sulianto Joko ${ }^{3}$}

1,2,3 SD N Tlogomulyo, Indonesia

\section{ART ICLE INF O}

Article history:

Received June 13, 2021

Revised June 15, 2021

Accepted September 12, 2021

Available online October 25, 2021

Kata Kunci:

Kemampuan Penalaran

Matematika, Bahan Poligon

Keywords:

Mathematical Reasoning Ability; Polygon Materials

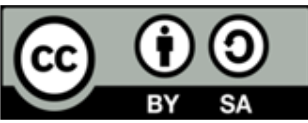

This is an open access article under the CC BY-SA license.

Copyright $(2021$ by Author. Published by Universitas Pendidikan Ganesha.

\begin{abstract}
A B S T RAK
Penalaran matematis merupakan salah satu landasan dalam memahami matematika dan merupakan bagian terpenting dalam menggambarkan kesimpulan yang valid tentang ide-ide dan hubungannya. Hanya saja kemampuan penalaran matematis siswa pada satu materi dengan materi lainnya cenderung berbeda. Penelitian ini bertujuan untuk menganalisis kemampuan penalaran matematis siswa kelas IV SD pada materi poligon. Penelitian ini termasuk penelitian kualitatif dengan tipe non-interaktif. Populasi dalam penelitian ini adalah 240 siswa sekolah dasar. Sampel dalam penelitian dilakukan dengan menggunakan teknik simple random sampling dengan jumlah sampel akhir 40 siswa kelas IV SD. Pengumpulan data dilakukan dengan menggunakan metode observasi, wawancara, dan tes dengan instrumen penelitian untuk menguji kemampuan penalaran matematis siswa. Analisis data hasil penelitian dilakukan dengan menggunakan metode analisis interaktif berdasarkan tahapan reduksi data, penyajian data, dan penarikan kesimpulan. Hasil analisis data menunjukkan bahwa rata-rata kemampuan penalaran matematis siswa adalah 61,90, dengan persentase $62 \%$ yang berada pada kategori sedang. Oleh karena itu, kemampuan penalaran matematis siswa pada materi banyak segi tergolong teori sedang. Sebagian siswa belum memahami konsep materi dari segi banyak, sehingga proses pembelajaran masih memerlukan bimbingan dari guru dan orang tua.
\end{abstract}

\section{A B S T R A C T}

Mathematical reasoning is one of the foundations in understanding mathematics and is the most important part of describing valid conclusions about ideas and their relationships. It's just that the mathematical reasoning ability of students on one material with other materials tends to be different. This study aimed to analyze the mathematical reasoning abilities of grade IV elementary school students on polygons materials. This research belongs to qualitative research of non-interactive types. The population in the study was 240 elementary school students. The sample in the study was carried out using simple random sampling techniques with the final sample number of 40 students in grade IV elementary school. Data collection was done using observation methods, interviews, and tests with research instruments to test students' mathematical reasoning ability. Data analysis conducted the research results using interactive analysis methods based on the stage of data reduction, presentation of data, and conclusion. The results of the data analysis showed that the average mathematical reasoning ability of students was 61.90 , with a percentage of $62 \%$ who were in the moderate category. Therefore, students' mathematical reasoning ability in many-faceted materials is classified as a medium theory. Some students do not understand the concept of material in terms of many, so the learning process still requires guidance from teachers and parents.

\section{INTRODUCTION}

The key to civilization and the progress of a nation can be seen in the quality of its education. This can be seen from the phenomenon that develops in the community, namely, the better the quality of education, the better the quality of human resources in the region, and the opposite (Nurmalasari \& Karimah, 2020). Through education, one will become a better person to improve the quality of life and be accepted in society (Sholihah \& Firdaus, 2019; Widyanto, 2020). The education process is not separated from the learning process. A good learning process is a learning process that makes active learners independently develop various abilities that exist in them through a student-centred learning process 
(Yulianti \& Wulandari, 2021). Learners active in the learning process will make learning more meaningful, later impacting learners' acquisition of learning experiences and emotional social development (Angela, 2014; Bressington et al., 2018; Kostiainen et al., 2018). One of the learning points that provide experience to learners in mathematics lessons. Mathematics is the basic science underlies and serves various other sciences (Wahyuni et al., 2019). In mathematics subjects, students are taught about definite sciences such as numbers, shapes, and concepts relating to logical truth, using common symbols and applied in other fields with axiomatic deductive characteristics (Isnaeni et al., 2018; Salmina \& Nisa, 2018). Students are expected to develop well because mathematics has a strong and clear structure and the interrelationship between concepts (Wibowo, 2017). The purpose of the implementation of mathematical learning is for students can use reasoning on patterns and traits, perform mathematical manipulation in making generalizations, compiling evidence, or explaining mathematical ideas and statements (Fadillah, 2019; Kusumaningtyas et al., 2021; Sofyana \& Kusuma, 2018).

However, mathematics is still one of the learnings that should be avoided. Because learners assume that mathematics is a difficult subject causing many students to be lazy to follow math learning (Nisa et al., 2021; Permatasari, 2021), it will impact the learners learning outcomes. This condition complies with the preliminary observations, where the observation results showed that the average mathematical value occupies the lowest position with 72,675. Low student math learning outcomes tend to be caused because students have not memorized multiplication, poor student memory, passive students when learning process, students tend to be silent when having difficulty working on problems, and some math materials cannot be mastered. In other words, the low learning outcome is caused by the learners thinking ability to understand the material presented (Firnanda \& Pratama, 2020; Hanifah et al., 2019). Therefore, in mathematics learning, thinking is needed in solving the problems given.

One of the abilities to think learners must possess is the ability of mathematical reasoning. Mathematical reasoning ability is also the ability to provide reasons for solving problems (Hidayat \& Sariningsih, 2020). The ability of reasoning in learners will easily understand mathematical concepts (Iim, 2021; Princess et al., 2019). This is because reasoning is a basic ability that can help students solve math problems encountered both in school and in everyday life (Islami et al., 2020; Salmina \& Nisa, 2018; Holy \& Taufina, 2020). However, not all students can master mathematical reasoning well. Some research that has been done before revealed that the level of students' mathematical reasoning ability in completion is still low. This is because students still do not understand the problem and preconceptions, and students still do not have an attitude of learning independence (Isnaeni et al., 2018). The research results reveal a slightly different: the students' mathematical reasoning ability in third-dimensional material is still relatively moderate, so it still needs improvement (Wahyuni et al., 2019). The research results state that students' mathematical reasoning abilities on function limit materials are high (Yusdiana \& Hidayat, 2018). The results of previous studies showed that the students' mathematical reasoning ability in each material is different, depending on the difficulty of the material as well as the ability of the student. For this reason, the current research aims to analyze the mathematical reasoning skills of grade IV elementary school students on polygon materials. It is for finding out how the mathematics reasoning ability will help teachers find the best solution for math learning.

\section{METHOD}

The research approach presented in this research was qualitative research of non-interactive types with analytical methods. The study was conducted at SD N Tlogomulyo with 240 students. The research samples were carried out using simple random sampling techniques with the final sample number of 40 students in grade IV. Data collection was done using observation methods, interviews, and tests. The instrument used is a test of mathematical reasoning ability consisting of 10 problems with ten different indicators. The ten mathematical reasoning indicators include understanding, logical thinking, understanding negative examples, deduction thinking, systematic thinking, consistent thinking, drawing conclusions, determining methods, making excuses, and determining strategies. The data analysis used interactive methods based on the data reduction stage, presentation, and conclusion. Data reduction was done by summarizing, choosing the main things, focusing on the important things, looking for themes and patterns, and discarding the unnecessary. Then, the reduced data will provide a clearer result and make it easier for researchers to collect the following data. After the data was collected, the analysis continued at the stage of data presentation. In qualitative research, the data presentation can be done through brief descriptions, charts, relationships between categories, flowcharts, etc. In this study, researchers will present data in a brief description of the analysis of the mathematical reasoning ability of grade IV in SD N Tlogomulyo. The data that has been presented concluded based on the presentation of existing data related to the analysis of students' mathematical reasoning ability by describing the mathematical reasoning ability 
of students of grade IV in SD N Tlogomulyo Semarang in understanding mathematical concepts and describing the percentage of use of mathematical reasoning ability when solving mathematical reasoning problems.

\section{RESULT AND DISCUSSION}

Result

Mathematical reasoning ability tests are provided to students through a teacher intermediary. The student's mathematical reasoning ability test results can be seen in Table 1. The results showed that students' average mathematical reasoning ability falls into a moderate category with an average percentage score of $62 \%$. The score variables of each question item vary from 3.18 to 10.00 . The range or distance of the two scores was quite prominent and could even be used as a reference for which indicators have been mastered by students and are difficult to master. It seems that indicator understands the negative example has been mastered perfectly, inversely proportional to the indicator of systematic thinking that can only be mastered $30 \%$ of it.

Table 1. The Test result of Mathematical Reasoning Ability

\begin{tabular}{|c|c|c|c|c|}
\hline No & Reasoning Aspect & Score Average & Score Percentage & $\begin{array}{l}\text { Students' Ability } \\
\text { Classification }\end{array}$ \\
\hline 1 & Understand the definition & 8,13 & $81 \%$ & Very High \\
\hline 2 & Logical thinking & 6,20 & $62 \%$ & High \\
\hline 3 & $\begin{array}{l}\text { Understanding negative } \\
\text { examples }\end{array}$ & 10,00 & $100 \%$ & Very High \\
\hline 4 & Deduction thinking & 6,38 & $63 \%$ & High \\
\hline 5 & Systematic thinking & 3,18 & $30 \%$ & Low \\
\hline 6 & Consistent thinking & 7,73 & $77 \%$ & High \\
\hline 7 & Drawing conclusion & 4,75 & $48 \%$ & Moderate \\
\hline 8 & Determining methods & 5,88 & $59 \%$ & Moderate \\
\hline 9 & Making excuses & 5,13 & $52 \%$ & Moderate \\
\hline 10 & Determining strategies & 4,55 & $46 \%$ & Moderate \\
\hline & Average & 61,90 & $62 \%$ & Moderate \\
\hline
\end{tabular}

The classification of students' mathematical reasoning skills after working on the problem can be seen in Table 2. The classification results are known that there are three students whose mathematical reasoning ability was very low. 11 students are classified as low-skilled, 13 students are moderately capable, 12 students have high mathematical reasoning skills, and one student has very high mathematical reasoning skills. The lowest mathematical reasoning ability test score is ten, and the highest score obtained by grade IV students of SD N Tlogomulyo Semarang was 97.

Table 2. Classification of students' mathematical reasoning ability

\begin{tabular}{cccc}
\hline No. & $\begin{array}{c}\text { Classification of Mathematical } \\
\text { Reasoning Ability }\end{array}$ & Number of Students & Percentage \\
\hline 1 & Very Low & 3 & $7 \%$ \\
2 & Low & 11 & $27 \%$ \\
3 & Moderate & 13 & $33 \%$ \\
4 & High & 12 & $30 \%$ \\
5 & Very High & 1 & $3 \%$ \\
& Total & $\mathbf{4 0}$ & $\mathbf{1 0 0 \%}$ \\
\hline
\end{tabular}

\section{Discussion}

The analysis results showed that the mathematical reasoning ability of students in polygon materials belonged to the moderate category. These results showed that not all students could use mathematical reasoning well. Then, it needed teachers' guidance in the learning process. The process of mathematical reasoning is essentially the foundation in understanding mathematics and is the most important part of describing valid conclusions about ideas and the relationships between them (Kusumawardani et al., 2018; Sihombing et al., 2021). It can be known that reasoning has an important role in having a very important role in the student's thought process (Widiati et al., 2020). If students' reasoning ability is not developed, mathematical learning will only emphasize concepts without knowing the meaning 
and implementation of the concepts presented (Fajriyah \& Zanthy, 2019; Izzah \& Azizah, 2019; Octriana et al., 2019).

Mathematical reasoning is classified into two types, namely inductive reasoning and deductive reasoning (Pitriati, 2019; Siregar, 2019). Inductive reasoning is based on a limited number of cases or examples that can be observed (Imran, 2018; Nababan, 2020). In contrast, deductive reasoning is based on general principles and knowledge that can lead learners to a general conclusion (Fadillah, 2019; Beautiful \& Nuraeni, 2021). Students' mathematical reasoning abilities can be improved by developing student independence attitudes (Syaripuddin et al., 2020). The attitude of independence refers to where students no longer rely on information or subject matter provided by teachers, but students themselves can seek from books or other sources. One of the attitudes in solving such problems is the independence of learning to find reasons from various basic knowledge which students give the right decision (Nasution et al., 2020).

The learning process that emphasizes students' independence to learn about teaching materials and reconstruct their knowledge follows the demands of learning in the 2013 curriculum (Efendi et al., 2021), as it has been known that learning in the 2013 curriculum is student-centred (Sofyan, 2019). To develop students' active role in developing mathematical reasoning ability, teachers must apply appropriate models and learning methods. Using appropriate models and learning methods, students' assumptions about difficult math learning can be reduced. The results obtained in this study are in line with the previous research results, which revealed that students' mathematical reasoning abilities in thirddimensional material are still relatively moderate. Thus, it still needs improvement (Wahyuni et al., 2019). The results of research on students' mathematical reasoning skills also revealed that students are still at a low level in solving the problem of reasoning ability. Students still do not understand the problem and preconceptions and still do not have an attitude of learning independence (Isnaeni et al., 2018). Other research revealed a slightly different thing where the students' mathematical reasoning ability on function limit materials is in the high category (Yusdiana \& Hidayat, 2018). Then, based on some previous studies, it can be concluded that the student's reasoning ability in each mathematical learning material tends to be different. In mathematical reasoning abilities on polygon materials, students are in the moderate category in the material. It meant that it still needed improvement.

\section{CONCLUSION}

The students' mathematical reasoning ability in polygon materials is classified as moderate. Some students still do not understand the material concept in many ways. Therefore, the learning process still requires guidance from teachers and parents. The indicator determines the strategy's lowest average score from the ten students' reasoning ability indicators. The result suggested that learning mathematics is considered necessary or a learning model familiarizes learners to develop reasoning ability.

\section{REFERENCES}

Angela, T. (2014). Challenges to Meaningful Learning in Social Studies - The Key Competencies as an Opportunity to Students' Active Participation. Procedia - Social and Behavioral Sciences, 128, 192197. https://doi.org/10.1016/j.sbspro.2014.03.142.

Bressington, D. T., Wong, W. kit, Lam, K. K. C., \& Chien, W. T. (2018). Concept mapping to promote meaningful learning, help relate theory to practice and improve learning self-efficacy in Asian mental health nursing students: A mixed-methods pilot study. Nurse Education Today, 60(February 2017), 47-55. https://doi.org/10.1016/j.nedt.2017.09.019.

Efendi, I., Prawitasari, M., \& Susanto, H. (2021). Implementasi Penilaian Pembelajaran Pada Kurikulum 2013 Mata Pelajaran Sejarah. Prabayaksa: Journal of History Education, 1(1), 21. https://doi.org/10.20527/prb.v1i1.3081.

Fadillah, A. (2019). Analisis Kemampuan Penalaran Deduktif Matematis Siswa. JTAM / Jurnal Teori Dan Aplikasi Matematika, 3(1), 15. https://doi.org/10.31764/jtam.v3i1.752.

Fajriyah, L., \& Zanthy, L. S. (2019). Penerapan Pendekatan Kontekstual Terhadap Kemampuan Penalaran Matematis Siswa SMP. Jurnal on Education, https: //doi.org/https://doi.org/10.31004/joe.v1i3.140.

Firnanda, V., \& Pratama, F. W. (2020). Profil Kemampuan Pemecahan Masalah Matematika Pada Materi Segitiga Berdasarkan Teori Van Hielle. Mosharafa: Jurnal Pendidikan Matematika, 9(3), 487-498. https://doi.org/10.31980/mosharafa.v9i3.775.

Hanifah, H., Supriadi, N., \& Widyastuti, R. (2019). Pengaruh Model Pembelajaran E-learning Berbantuan Media Pembelajaran Edmodo Terhadap Kemampuan Pemecahan Masalah Matematis Peserta Didik. NUMERICAL: Jurnal Matematika Dan Pendidikan Matematika, 3(1), 31-42. 
https://doi.org/10.25217/numerical.v3i1.453.

Hidayat, W., \& Sariningsih, R. (2020). Profil Kemampuan Penalaran Kreatif Matematis Mahasiswa Calon Guru. Jurnal Elemen, 6(1), 108-127. https://doi.org/10.29408/jel.v6i1.1738.

Iim, M. (2021). Kemampuan Penalaran Matematis Siswa dengan Model Pembelajaran Pair. Jurnal Revolusi Indonesia, 1(2). https://doi.org/https://doi.org/10.1235/jri.v1i2.66.

Imran, N. 'Afifah. (2018). Pengaruh Pendekatan Scientific Terhadap Kemampuan Pelanaran dan Komunikasi Matematika. Jurnal Pendidikan: Teori, Penelitian, Dan Pengembangan, 1(2), 51-60.

Indah, P., \& Nuraeni, R. (2021). Perbandingan Kemampuan Penalaran Deduktif Matematis Melalui Model PBL dan IBL Berdasarkan KAM. Mosharafa: Jurnal Pendidikan Matematika, 10(1), 165-176. https://doi.org/10.31980/mosharafa.v10i1.931.

Islami, A. N., Rahmawati, N. K., \& Yulianto, W. (2020). Eksperimentasi Model Student Facilitator and Explaining dan Probing-Prompting Ditinjau dari Penalaran Matematis. Journal of Instructional Mathematics, 1(2), 83-90. https://doi.org/10.37640/jim.v1i2.687.

Isnaeni, S., Fajriyah, L., Risky, E. S., Purwasih, R., \& Hidayat, W. (2018). Analisis Kemampuan Penalaran Matematis dan Kemandirian Belajar Siswa SMP pada Materi Persamaan Garis Lurus. Journal of Medives: Journal of Mathematics Education IKIP Veteran Semarang, 2(1), 107. https://doi.org/10.31331/medives.v2i1.528.

Izzah, K. H., \& Azizah, M. (2019). Analisis Kemampuan Penalaran Siswa dalam Pemecahan Masalah Matematika Siswa Kelas IV. Indonesian Journal of Educational Research and Review, 2(2), 210. https://doi.org/10.23887/ijerr.v2i2.17629.

Kostiainen, E., Ukskoski, T., Ruohotie-Lyhty, M., Kauppinen, M., Kainulainen, J., \& Mäkinen, T. (2018). Meaningful learning in teacher education. Teaching and Teacher Education, 71, 66-77. https://doi.org/10.1016/j.tate.2017.12.009.

Kusumaningtyas, N., Parta, I. N., \& Susanto, H. (2021). Kemampuan Penalaran Matematis Siswa dalam Memecahkan Masalah Matematika pada Saat Pembelajaran Daring. Jurnal Cendekia: Jurnal Pendidikan Matematika, 6(1), 107-119. https://doi.org/10.31004/cendekia.v6i1.1019.

Kusumawardani, D. R., Wardono, \& Kartono. (2018). Pentingnya Penalaran Matematika dalam Meningkatkan Kemampuan Literasi Matematika. Prisma, 1(1), 588-595.

Nababan, S. A. (2020). Analisis Kemampuan Penalaran Matematis Siswa Melalui Model Problem Based Learning. JISIP (Jurnal Ilmu Sosial Dan Pendidikan), 4(3), 6-12. https://doi.org/10.36312/jisip.v4i3.1239.

Nasution, E. Y. P., Gunawan, R. G., \& Yulia, P. (2020). Pengaruh Model Pembelajaran Problem Based Instruction (PBI) terhadap Kemampuan Penalaran Matematis Siswa. Logaritma : Jurnal Ilmu-Ilmu Pendidikan Dan Sains, 7(02), 163-176. https://doi.org/10.24952/logaritma.v7i02.2113.

Nisa, A., Amir, Z., \& Vebrianto, R. (2021). Problematika Pembelajaran Matematika di SD Muhammadiyah Kampa Full Day School. El-Ibtidaiy:Journal of Primary Education, 4(1), 95. https://doi.org/10.24014/ejpe.v4i1.11655.

Nurmalasari, I., \& Karimah, D. Z. (2020). Peran Manajemen SDM dalam Lembaga Pendidikan untuk Meningkatkan Mutu Pendidik. MANAGERE : Indonesian Journal of Educational Management, 2(1), 33-44. https://doi.org/10.52627/ijeam.v2i1.14.

Octriana, I., Putri, R. I. I., \& Nurjannah, N. (2019). Penalaran Matematis Siswa Dalam Pembelajaran Pola Bilangan Menggunakan Pmri Dan Lslc. Jurnal Pendidikan Matematika, 13(2), 131-142. https://doi.org/10.22342/jpm.13.2.6714.131-142.

Permatasari, K. G. (2021). Problematika Pembelajaran Matematika di Sekolah Dasar / Madrasah Ibtidaiyah. Jurnal Ilmiah Pedagogy, 17(20).

Pitriati, P. (2019). Pembelajaran Matematika Menggunakan Model Learning Cycle 5E Untuk Meningkatkan Kemampuan Penalaran Matematis Siswa SMP 30 Padang. Indonesian Journal of Science and Mathematics Education, 2(2), 235-244. https://doi.org/10.24042/ijsme.v2i2.4397.

Putri, D. K., Sulianto, J., \& Azizah, M. (2019). Kemampuan Penalaran Matematis Ditinjau dari Kemampuan Pemecahan Masalah. International Journal of Elementary Education, 3(3), 351. https://doi.org/10.23887/ijee.v3i3.19497.

Salmina, M., \& Nisa, S. K. (2018). Kemampuan Penalaran Matematis Siswa Berdasarkan Gender pada Materi Geometri. Jurnal Numeracy, 1000-1008. https://doi.org/https://doi.org/10.46244/numeracy.v5i1.304.

Sholihah, I., \& Firdaus, Z. (2019). Peningkatan kualitas sumber daya manusia melalui pendidikan. Jurnal AlHikmah, 7(2), 33-46.

Sihombing, C. E., Lubis, R., \& Ardiana, N. (2021). Analisis Kemampuan Penalaran Matematis Siswa Selama Pandemi Covid-19 Ditinjau dari Minat Belajar Siswa. JURNAL MathEdu (Mathematic Education Journal), 4(2), 285-295. https://doi.org/10.37081/mathedu.v4i2.2540. 
Siregar, N. (2019). Upaya Meningkatkan Kemampuan Penalaran dan Komunikasi Matematis Siswa Melalui Model Pace. Pedagogy: Jurnal Pendidikan Matematika, 4(2), 58-70. https://doi.org/10.30605/pedagogy.v4i2.1443.

Sofyan, F. A. (2019). Implementasi Hots Pada Kurikulum 2013. INVENTA, 3(1), 1-9. https://doi.org/10.36456/inventa.3.1.a1803.

Sofyana, U. M., \& Kusuma, A. B. (2018). Upaya Meningkatkan Kemampuan Penalaran Matematis Siswa Menggunakan Pembelajaran Generative pada Kelas VII SMP Muhammadiyah Kaliwiro. Kontinu: Jurnal Penelitian Didaktik Matematika, 2(1), 14. https://doi.org/10.30659/kontinu.2.1.14-29.

Suci, D. W., \& Taufina, T. (2020). Peningkatan Pembelajaran Matematika Melalui Strategi Berbasis Masalah di Sekolah Dasar. Jurnal Basicedu, 4(2), 505-512. https://doi.org/10.31004/basicedu.v4i2.371.

Syaripuddin, S., Fauzi, A., \& Ariswoyo, S. (2020). Peningkatan Kemampuan Penalaran Matematis Siswa MTS Melalui Pendekatan Metakognitif. Jurnal Matheducation Nusantara, 3(2). https://doi.org/https://doi.org/10.32696/jmn.v3i2.142.

Wahyuni, Z., Roza, Y., \& Maimunah, M. (2019). Analisis Kemampuan Penalaran Matematika Siswa Kelas X pada Materi Dimensi Tiga. Jurnal Ilmiah Pendidikan Matematika Al Qalasadi, 3(1), 81-92. https://doi.org/10.32505/qalasadi.v3i1.920.

Wibowo, A. (2017). Pengaruh pendekatan pembelajaran matematika realistik dan saintifik terhadap prestasi belajar, kemampuan penalaran matematis dan minat belajar. Jurnal Riset Pendidikan Matematika, 4(1), 1. https://doi.org/10.21831/jrpm.v4i1.10066.

Widiati, Y., Kamid, K., \& Anggerein, E. (2020). Analisis Kemampuan Penalaran Matematis Ditinjau dari Persepsi Siswa Terhadap Materi Operasi Aljabardi Kelas VII SMP. JP3M Uurnal Penelitian Pendidikan Dan Pengajaran Matematika), 6(2), 83-90. https://doi.org/10.37058/jp3m.v6i2.1951.

Widyanto, I. P. (2020). Peningkatan Mutu Pendidikan Hindu Melalui Pengelolaan Pembelajaran. Jurnal Penjaminan Mutu, 6(1), 48. https://doi.org/10.25078/jpm.v6i1.1151.

Yulianti, Y. A., \& Wulandari, D. (2021). Flipped Classroom : Model Pembelajaran untuk Mencapai Kecakapan Abad 21 Sesuai Kurikulum 2013. Jurnal Hasil Penelitian Dan Kajian Kepustakaan Di Bidang Pendidikan, Pengajaran Dan Pembelajaran, 7(2), 372. https://doi.org/10.33394/jk.v7i2.3209.

Yusdiana, B. I., \& Hidayat, W. (2018). Analisis Kemampuan Penalaran Matematis Siswa SMA pada Materi Limit Fungsi. JPMI (Jurnal Pembelajaran Matematika Inovatif), 1(3), 409. https://doi.org/10.22460/jpmi.v1i3.p409-414. 